УДК 323:316.4

https://doi.org/10.34142/24130060.2019.17.1.03

\title{
МОБІЛІЗАЦЙННЙ̆ ПОТЕНЦІАЛ СУСПІЛЬСТВА РИЗИКУ: ПОЛІТОЛОГІЧНИЙ АСПЕКТ
}

\author{
O.O. Безрук \\ Харківський національний педагогічний університет імені Г.С. Сковороди
}

Розглянуто аспект використання мобілізаційного потениіалу суспільства в контексті проблеми «суспільства ризику» та основні конщепції «суспільства ризику» як специфічного стану сучасних суспільств в умовах високого ступеня невизначеності. Констатовано, щзо в сучасних умовах спроби подолання ризиків породжують нові ризики $i$ безпека стає дефіиитним ресурсом існування індивіду та суспільства в иілому, а сочіально-політична нестабільність розмиває традииійні механізми забезпечення індивідуальної безпеки, посилює невпевненість особистості у власній захищеності, поширює зони ризику та загроз.

Охарактеризовано мобілізаційний потенціал суспільства як інструменту нейтралізації викликів та інших небезпек з метою збереження основних інститутів та власних підсистем. Запропоновані основні складові мобілізаційного потенціалу, зокрема, економічний, демографічний, політичний.

Проаналізовано прояви рис суспільства ризику в Україні. Виявлено основні чинники, які впливають на якість мобілізаційного потенціалу українського суспільства.

Ключові слова: суспільство ризику, мобілізачійний потенціал, безпека, політична система.

\section{МОБИЛИЗАЦИОННЫЙ ПОТЕНЦИАЛ ОБЩЕСТВА РИСКА: ПОЛИТОЛОГИЧЕСКИЙ АСПЕКТ}

\section{А.А. Безрук}

Рассмотрены аспект использования мобилизационного потенщиила общества в контексте проблемь «общества риска» и основные концепџии «общества риска» как специфического состояния современных обществ в условиях высокой степени неопределенности. Констатировано, что в современных условиях попытки преодоления рисков порождают новые риски и безопасность становится дефицитным ресурсом существования индивида и общества в целом, а соџиально-политическая нестабильность размывает традиционные механизмы обеспечения индивидуальной безопасности, усиливает неуверенность личности в собственной защищенности, распространяет зоны риска и угроз.

Охарактеризован мобилизащионный потенциал общества как инструмент нейтрализации вызовов и других опасностей с иелью сохранения основных институтов и собственных подсистем. Предложены основные составляющие мобилизационного потенциала, в частности, экономический, демографический, политический.

Проанализировань проявления черт общества риска в Украине. Выявлень основные факторы, влияющие на качество мобилизационного потенцииала украинского общества.

(C) О.О. Безрук, 2019 
Ключевые слова: общество риска, мобилизационный потенциал, безопасность, политическая система.

\section{THE MOBILIZATIONAL POTENTIAL OF RISK SOCIETY: THE POLITICAL ASPECTS}

\section{O. Bezruk}

The aspect of using the mobilization potential of society in the context of the problem of «society of risk» and the main concepts of «society of risk» as a specific state of modern societies in conditions of high degree of uncertainty is considered. It is stated that under present conditions, attempts to overcome risks create new risks and safety becomes a scarce resource for the existence of the individual and society as a whole, while socio-political instability erodes the traditional mechanisms of providing individual security, increases the uncertainty of the individual in his own security, spreads risk areas and threats. The main dimensions of individual security are presented: objective and subjective. It was emphasized that risk societies remain at the forefront of socio-political development, despite the increase of general instability.

The mobilization potential of society as a tool for neutralizing the challenges and other dangers is described in order to preserve the main institutions and their own subsystems. The main components of the mobilization potential, in particular economic, demographic, and political, are offered.

The manifestations of the features of a society of risk in Ukraine are analyzed. It is alleged that Ukraine is in special conditions of actualized danger and developmental risks, and mobilization potential serves as a substantial, existential asset, the basis for the preservation of statehood in a harsh confrontation. It is indicated that the operational reaction of the political system and civil society is the key to a rational search for an optimal solution to the crisis and the use of available opportunities.

The main characteristics of the state of danger in Ukraine are presented. The main factors influencing the quality of the mobilization potential of Ukrainian society are revealed.

Key words: risk society, mobilization potential, security, political system.

Постановка проблеми. Сучасна фаза розвитку людства, яка окремими дослідниками визначається категорією «суспільство ризику» актуалізує низку проблем: безпеки, забезпечення стійкого розвитку, обмеження розповсюдження ризиків тощо. Небезпеки, які притаманні даному суспільству, принципово відрізняються тим, що не мають кордонів ні в просторі, ні у часі. Державні кордони для цих небезпек не є перепонами.

Важливим аспектом щодо обмеження ризиків та відповіддю на сучасні виклики виступає мобілізаційний потенціал суспільства. Мобілізаційний потенціал характеризується, в першу чергу, можливостями суспільства нейтралізовувати виклики та інші небезпеки з метою збереження основних інститутів та власних підсистем. Суспільства ризику на відміну від, наприклад, традиційних суспільств, функціонують в умовах невизначеності, 
що вимагає підтримання високого рівня якості мобілізаційного потенціалу, самоорганізації, сінергії, конструктивної взаємодії між суспільством та політичною системою.

Аналіз актуальних досліджень. Теоретичний аналіз проблеми ризиків представлено в наукових розвідках західних та вітчизняних вчених У. Бека, А. Вілдавскі, Е. Гідденса, М. Дуглас, Н. Лумана, М. Балана, В. Воронкової, А. Приятельчука, О. Яницького та інших.

Наукові дослідження мобілізаційного потенціалу представлені в обмеженому обсязі. Різні аспекти цього процесу розглянуто в роботах Г. Девіса, Р. Маквея, К. Рутеса, Х. Ін Хуей, О. Гріненка, М. Дєнєжкіна, О. Кутового, Н. Махначової, В. Перевезія.

Метою статті є розгляд та теоретичний аналіз ролі мобілізаційного потенціалу суспільства ризику як основи забезпечення функціонування даного типу суспільств.

Завдання дослідження: розгляд та аналіз основних концепцій суспільства ризику; інтерпретація мобілізаційного потенціалу суспільства як основного ресурсу по зниженню рівня ризиків на сучасному етапі розвитку; виокремлення основних чинників мобілізаційного потенціалу українського суспільства на тлі актуалізованих небезпек.

Виклад основного матеріалу. Основною причиною виникнення «суспільства ризику», на думку У.Бека $є$ глобальна зміна виробничих відносин, що почалося в другій половині ХХ ст. Ризик інтерпретується як імовірність фізичної загрози, що є наслідком, насамперед, технологічних процесів. У. Беком зазначено, що з розвитком технологічної та наукової бази ризики не тільки не зникають, але виробляються в ще більшій кількості. Ризики починають загрожувати не тільки життю індивіда, але i всьому суспільству в цілому. Виробництво ризиків здійснюється не тільки на підприємствах, але і у всіх сферах життєдіяльності суспільства: економічній, політичній, соціальній, що стає особливістю ризиків модернізації (Бек, 2000). 
Головною особливістю сучасних ризиків $є$ їхня відмінність від руйнувань, породжених війною, їх «нормальним» або, точніше, їх «мирним» породженням (виробництвом) в центрах раціональності і Просвітництва, 3 благословення та за гарантії закону і соціального порядку (Бек, 2000).

Вони стабільно відтворюються суспільством в економічній, політичній, соціальній сферах життєдіяльності, будучи результатом прийняття рішень. «Суспільство ризику» - це суспільство, яке генерує ризики. Базова проблема «суспільства ризику» полягає у неможливості дистанціювання від ризиків в сучасному світі, що актуалізує проблему мінімізації ризиків і управління НИМи.

Згідно концепції Н. Лумана, ризик приймає формальне вираження у вигляді ймовірності. Він пропонує власний підхід для вивчення поняття «ризик»: визначення має починатися із з'ясування протилежного поняття або шляхом «розрізнення відмінностей». Для цього він порівнює поняття «ризик» 3 поняттями «небезпека» $\mathrm{i}$ «надійність». У парі «ризик/небезпека» Н. Луман (1994) починає «розрізнення відмінностей» зі з’ясування мовних значень.

Розрізнення цих понять, за Н. Луманом, передбачає, що існує невпевненість щодо майбутнього збитку. Можливі два варіанти результатів. 3 одного боку, можливі наслідки розглядаються як результат прийнятого індивідом рішення. Тоді можна говорити про ризик як про ризик прийняття рішення і про ризики, пов'язані з неправильним вибором. 3 іншого боку, вважається, що причини наслідків знаходяться у навколишньому світі. У сучасному суспільстві кожне рішення тягне за собою ризик.

Е. Гідденс порівнює сучасний світ 3 системою, структурними елементами якої є ризики, що створюються людством. Він виокремлює властиві їм специфічні ознаки: обумовленість сучасних ризиків глобалізацією, що призводить до збільшення чисельності взаємозалежних подій; виникнення «інституалізованих середовищ ризиків»; проблема 
перенасиченості сучасного суспільства знаннями про ризики; недостатність експертного знання як інструменту усунення ризиків в соціальних системах.

Е. Гідденс вводить також поняття «середовище ризику» в сучасному суспільстві. «Середовище ризику» включає в себе наступні елементи: ризики, що породжуються рефлективністю модернізації; загроза усвідомлення і виникнення почуття безглуздості існування людини, що обумовлена спробами людини у віднесенні свого особистого буття 3 рефлективною модернізацією; небезпека для людства, викликається модернізацією та вдосконаленням військових технологій (Гидденс, 1994).

На думку Е. Гідденса, 3 переходом на наступний етап розвитку суспільства i технологій, буде досягнутий високий рівень безпеки, незважаючи на те, що процес модернізації лише сприяв появі нових ризиків, а глобалізація вплинула на ступінь їх поширення. Е. Гідденс звертає особливу увагу на те, що тепер не лише дія, а й відмова від прийняття рішень може привести до виникнення ризиків. Бездіяльність виникає тому, що, не усунувши наслідки одного ризику, суспільство актуалізує новий, іноді набагато більш істотний і складний ризик.

М. Дуглас, в свою чергу, пропонує вивести визначення ризику через безпосередній розгляд самих ситуацій ризику. Вивчення ризику, на їі думку, марно без урахування культурологічних особливостей про-суспільством. Це пов’язано $з$ тим, що ризик конструюється самим індивідом залежно від його цілей, цінностей та інтересів. Особливий вплив на індивіда в момент сприйняття ризику надають його культурні установки і практики, а також засвоєна ним у процесі життєдіяльності інформація.

Згідно М. Дуглас (2000), ситуація ризику означає, що індивід виходить за рамки структури суспільства і опиняється у пограничному стані. У цей момент індивід знаходиться під впливом сил або небезпек, здатних змінити його статус у суспільстві.

М. Дуглас стверджує, що рішення за них повинні приймати інші. Вона пояснює зроблений нею висновок тим, що ці індивіди через свою 
непричетність до загальної системи взаємин не здатні на прийняття релевантних рішень, які в подальшому не позначилися б ні на їх життєдіяльності, ні на усьому суспільстві у цілому.

О. Яницький $(2003$, с. 31) вказує, що «...не розвиток, а безпека стає головним орієнтиром діяльності соціальних акторів та соціальних інститутів». Особливо це стосується перехідних суспільств.

3 вищевикладеного вимальовується песимістична картина: спроби подолання ризиків породжують нові ризики і коло замикається. Тому безпека стає дефіцитним ресурсом існування індивіду та суспільства в цілому. Безпека особистості виступає окремим аспектом комплексного поняття «безпека», є елементом національної безпеки, входячи в тріаду «безпека особисті - суспільна безпека - державна безпека». Можна окреслити два основні виміри безпеки особистості (індивідуальної безпеки):

суб’єктивний - внутрішне почуття захищеності в ситуаціях повсякденності та впевненість екзистенційного характеру, яка є наслідком довіри до інститутів безпеки, в першу чергу - держави;

об’єктивний - стан забезпеченості прав і свобод індивідів, як результат цілеспрямованої діяльності міжнародних, державних, громадських та інших структур.

Соціально-політична нестабільність розмиває традиційні механізми забезпечення індивідуальної безпеки, посилює невпевненість особистості у власній захищеності, поширює зони ризику та загроз.

Значним політичним моментом залишається діяльність державних інститутів в сфері забезпечення безпеки особистості. Внаслідок процесів глобалізації, підвищення рівня громадянської активності та швидкості поширення інформації, більшість сучасних держав послаблюють свій вплив у цій безпековій сфері де-факто. «Національна держава вже не спроможна ефективно функціонувати в рамках іiі традиційних повноважень, зокрема, належним чином забезпечуючи всебічні права i свободи громадян» (Шароватова, 2014, с.67). 
Таким чином, ризик, як форма небезпеки, постає суттєвим чинником протікання повсякденних процесів: політичних, економічних, соціальних тощо. Тим не менш, суспільства ризику залишаються в авангарді суспільнополітичного розвитку, незважаючи на посилення загальної нестабільності.

Окремим аспектом забезпечення такого нестійкого status quo та ресурсом подолання ризиків виступає мобілізаційний потенціал.

Взагалі, мобілізаційний потенціал є комплексним поняттям, яке містить низку складових. В українській і зарубіжній науковій літературі називається більше тридцяти потенціалів, що впливають на стан загальної потужності країн і коаліцій: економічний, науково-технічний, політичний, соціальний, демографічний, моральний, військовий та ін. Роль різних потенціалів у формуванні можливостей держави неоднозначна. Можна навести наступні типи потенціалів:

військовий потенціал - здатність держави (коаліції) утримувати й удосконалювати збройні сили, підвищувати їх боєготовність і боєздатність, поповнювати навченими кадрами, постачати сучасними зброєю та військовою технікою, усіма видами постачання в мирний час і особливо в період війни;

економічний потенціал - об'єктивні можливості, якими володіє держава (коаліція), для виробництва матеріальних благ і послуг з метою задоволення цивільних і військових економічних потреб суспільства при максимальній напрузі сил. Його роль значно зростає в сучасних умовах у зв'язку з освоєнням збройними силами якісно нових систем озброєння, військової та спеціальної техніки в кількостях, необхідних для гарантованого захисту національної безпеки. Від рівня розвитку економічного потенціалу, стану економіки держави залежать кількісні та якісні параметри збройних сил;

демографічний потенціал - чисельність населення країни, району, населеного пункту тощо, що розглядається 3 точки зору відтворення 
населення i потенційно можливого числа зайнятих в галузях народного господарства та ін. (Словари и энциклопедии, 2015).

політичний потенціал, на думку автора, можна визначити як здатність політичних еліт (правлячої та неправлячої) узгоджувати спільні дії (пакт), що направлені як на підтримку внутрішньополітичної стабільності, так і на подолання зовнішніх викликів, які несуть загрози існуванню держави та суспільства. Політичний потенціал залежить від якісних характеристик еліт i є інтелектуальним компонентом усього блоку мобілізаційного потенціалу, в той час, як інші складові $є$ ресурсними компонентами. Релевантне використання ресурсів в період суспільно-політичних трансформацій і стає запорукою отримання конструктивних результатів.

Враховуючи вищезазначене, доцільно розглянути особливості стану мобілізаційного потенціалу та ризиків в Україні, як державі, котра знаходиться в особливих умовах актуалізованої небезпеки та ризиків розвитку.

Україна не подолала статус транзитивної держави, оскільки сучасний стан соціальної та політичної систем українського суспільства можна визначити як перехід до нової точки фазового простору. Цей перехід характеризується нерівномірним, дискретним поступом 3 періодичними поверненнями до попередніх локацій. Така ситуація детермінована канонічними вищевказаними внутрішніми чинниками, гібридним конфліктом та загальним міжнародним становищем. В таких умовах політична мобілізація суспільства (у певному сенсі - мобілізаційний потенціал) стає важливою змінною, від значення якої залежатиме ефективність функціонування вказаних систем.

Мобілізаційний потенціал виступає тут суттєвим, екзистенційним активом, основою збереження державності в умовах жорсткого протистояння, а оперативна реакція політичної системи та громадянського суспільства $\epsilon$ запорукою раціонального пошуку оптимального рішення виходу з кризи та використання наявних можливостей. 
Слід навести наступні характеристики стану небезпеки у сучасній Україні:

агресивні дії Росії, що здійснюються для виснаження української економіки і підриву суспільнополітичної стабільності з метою знищення держави Україна і захоплення іï території;

неефективність системи забезпечення національної безпеки і оборони України;

корупція та неефективна система державного управління;

економічна криза, виснаження фінансових ресурсів держави, зниження рівня життя населення;

загрози енергетичній безпеці;

загрози інформаційній безпеці;

загрози кібер-безпеці і безпеці інформаційних ресурсів;

загрози безпеці критичної інфраструктури;

загрози екологічній безпеці (Балан, 2019).

Здійснюючи попередній аналіз стану мобілізаційного потенціалу українського суспільства, доцільно враховувати наступні позитивні та негативні чинники, які впливають на його стан. Серед позитивних: достатньо високий рівень здатності громадян до консолідації в умовах актуалізованої небезпеки (це засвідчують феномени волонтерства та створення добровольчих батальйонів в період 2014-2015 pp.); високий рівень освіченості українських громадян; установки на цінності індивідуалізму серед активних вікових груп, що сприяє прийняттю оперативних рішень в надзвичайних умовах; достатній рівень політичної активності; досвід адаптації в трансформаційні та кризові періоди політичної та економічної історії тощо.

Серед негативних чинників, що послаблюють мобілізаційний потенціал суспільства, можна виокремити наступні: певні дисфункції політичної системи, викликані кризою 2013-2014 рр.; неефективність правової системи; тенденції депопуляції; бюрократизація, спотворення та гальмування 
політичних рішень; високий рівень недовіри суспільства до влади (Телеканал ZIK, 2017); прояви абсентеїзму, ретретизму та «над-індивідуалізму» в суспільстві і т. ін.

Висновки i перспективи подальших досліджень. Політична та соціальна реальності, що змінюються із великою швидкістю, змушують окремих членів суспільства і суспільство в цілому функціонувати в нових ситуаціях з високим ступенем невизначеності.

3 урахуванням поточного стану, в глобалізованому світі не підлягає сумніву твердження, що в найближчій перспективі світове співтовариство і кожна окрема держава будуть зіткатися із виробництвом нових ризиків при наявності ризиків неподоланих, які поступово утворять «критичну масу», що в свою чергу може призвести до радикальних трансформацій.

Таким чином, «суспільство ризику» залишатиметься сценарієм розвитку в XXI ст. і потребуватиме значних політичних, економічних та інших зусиль щодо підтримки «оптимального» рівня небезпеки. Ресурсною базою цієї підтримки слугуватиме саме мобілізаційний потенціал суспільства, дослідження стану якого виступає актуальною проблематикою сьогодення.

\section{ЛІТЕРАТУРА}

1. Балан, М.I., 2019. Суспільство ризику: дестабілізаційні можливості. Державне управління: удосконалення та розвиток, [online] 2 Доступно: http://www.dy.nayka.com.ua/pdf/2_2019/105.pdf [Дата звернення 02 лютий 2019]

2. Бек, У. 2000. Общество риска. На пути к другому модерну. Москва: ПрогрессТрадиция.

3. Гидденс, Э., 1994. Судьба, риск и безопасность. THESIS, [online] 5, с. 107-134 Доступно: http://riskprom.ru/TemaKtlg/RiskSociety/eh_giddens_sudba_risk_bezop_1991. pdf [Дата звернення 10 лютий 2019].

4. Дуглас, М. 2000. Чистота и опасность: анализ представлений об оскверненности и табу. Москва: КАНОН-ПРЕСС-Ц КУЧКОВО ПОЛЕ.

5. Луман, Н., 1994. Понятие риска. THESIS, [online] 5, с. 135-160 Доступно: https://igiti.hse.ru/data/423/313/1234/5_2_2Luhm.pdf [Дата обращения 11 січень 2019].

6. Словари и энциклопедии, 2015. Демографический потенциал. Словарь по географии. [online] Доступно: https://geography_ru.academic.ru/1979 [Дата звернення 10 січень 2019].

7. Телеканал ZIK, 2017. Соціологи виміряли рівень довіри українців до влад. [online] (Останнє оновлення 01 лютого 2017) Доступно: 
http://zik.ua/news/2017/02/01/sotsiology_vymiryaly_riven_doviry_ukraintsiv_do_vlady_1 035987 [Дата звернення 10 січень 2019].

8. Шароватова, О.П., 2014. Безпека особистості як соціокультурний феномен. Наукові записки НДУ імені М. Гоголя, [online] 4, с. 66-70 Доступно: file://C:/Users/Owner/Desktop/Nzspp_2014_4_14.pdf [Дата звернення 10 січень 2019].

9. Я Яницкий, О.Н., 2003. Социология риска: ключевые идеи. Мup Poccuи, [online] 1, с. 335 Доступно: https://cyberleninka.ru/article/v/sotsiologiya-riska-klyuchevye-idei [Дата звернення 10 січень 2019].

\section{Інформація про автора}

Безрук Олександр Олександрович - кандидат політичних наук, доцент, завідувач кафедри політології, соціології і культурології Харківського національного педагогічного університету імені Г.С. Сковороди; e-mail: alex.bezruk@ukr.net; ORCID: http://orcid.org/0000-0002-4963-570.

Стаття надійшла до редакції: 05.02.2019 р. $\quad$ Прийнята до друку: 18.02.2019 p. 